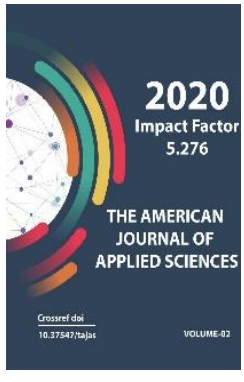

Journal Website: http://usajournalshub.c om/index,php/tajas

Copyright: Original content from this work may be used under the terms of the creative commons attributes 4.0 licence.

\section{The Elements Of Organization Of The Educational Process On The Basis Of New Pedagogical Technologies}

\author{
Saidov Safo Olimovich \\ Associate Professors Of The Department Of Physics, Bukhara State University, Uzbekistan \\ Atoeva Mexriniso Farkhodovna \\ Associate Professors Of The Department Of Physics, Bukhara State University, Uzbekistan \\ Fayzieva Kholida Asadovna \\ Senior Teachers Of The Department Of Physics Senior Teacher Of The Department Of Physics, \\ Bukhara State University, Uzbekistan \\ Yuldosheva Nilufar Bakhtiyorovna \\ Senior Teachers Of The Department Of Physics Senior Teacher Of The Department Of Physics, \\ Bukhara State University, Uzbekistan
}

\title{
ABSTRACT
}

The essence of the new pedagogical technology is the idea of full management of the educational process, which includes the establishment of learning objectives, the structure of the learning process and its effectiveness. The specificity of pedagogical technology is that learning objectives are formed by learning outcomes expressed in the levels of knowledge of students that the educator can confidently select or measure. In this article, we shall discuss the elements of organization of the educational process on the basis of new pedagogical technologies.

\section{KEYWORDS}

New pedagogical technology, learning objectives, teaching, set goals, evaluate results, learners

\section{INTRODUCTION}

In the new pedagogical technology, the basis of consistent orientation (goal) of the goals is the operative feedback. In this case, the learning objectives are defined as much as possible. From the beginning to the end of the teaching, it is important to focus on learning objectives, to achieve guaranteed results throughout the teaching, to evaluate daily results, to improve teaching to achieve the set goals and to evaluate the results. 
Improvement

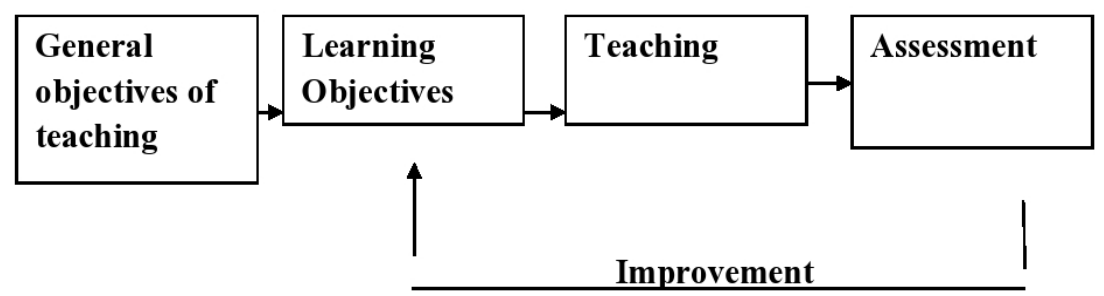

In the new pedagogical technology, the learning objectives are the most important factor and can be equated with the technological process diagram in the industry. The general objectives of teaching consist of a generalization of the learning objectives of each subject. The learning objectives of each subject should be developed very carefully based on the categories of knowledge. Teaching is based on these developed learning objectives. At the end of the training, the achieved results are evaluated, shortcomings, problems are identified, learning objectives and teaching methods are improved. The learning process, like the technological process in the industry, must be constantly evolving based on the above structure.

\section{MATERIALS AND RESULTS}

M.V.Klarin emphasizes that the key to understanding the technological structure of the learning process is a consistent orientation to clearly defined goals. In this regard, we turn to typical methods of goal setting in traditional teaching.

1. Defining goals through the content being studied. For example: "... study the content of such chapters (events, theorems, laws, etc.)." This method of setting goals does not find a clear goal to structure the learning process in one or more such definitions. Based on such definitions, is it possible to draw a conclusion (through measurements) about achieving this or that goal? Of course not. Accordingly, proponents of pedagogical technology believe that this method of goal setting is not sufficient.

2. Defining goals through pedagogical activity. For example: "Introduce students to the principle of operation of an internal combustion diesel engine. This way of setting goals (by the educator) is concentrated in his personal activities. This instrumental, non-technological method of goal setting is masked, but not overcome.

3. Setting goals through the internal processes of intellectual, emotional, personal development of the student. For example: to form the ability to analyze the observed phenomena. Proponents of pedagogical technology also completely reject this method of goal setting. In this method, it is not possible to find orientations (goals) to judge the achievement of the goal, because it is set at an extremely "procedural" level.

4. Setting goals through students' learning activities. The purpose of the lesson is to 
solve problems to determine the first product. For this purpose, the expected result of training, there is no indication of its consequences. The method of setting goals proposed by pedagogical technology is characterized by excessive instrumentalism (abundance of instruments). It is that learning objectives are shaped by the results expressed in students 'reliable measurements, the behaviors that can be learned. See the table below (Table 1) approved by Blum.

\section{RESULTS AND DISCUSSIONS}

This system of general methods of pedagogical goals in the field of knowledge has gained wide international fame. This includes goals ranging from memorizing and repeating learned material to existing rules, including solving problems that require innovation (creation).

\section{Categories Of Learning Objectives In The Field Of Cognition}

Table 1

\begin{tabular}{|c|c|}
\hline Categories of Basic Learning Objectives & $\begin{array}{l}\text { Generalization categories of learning } \\
\text { objectives } \\
\text { Examples: }\end{array}$ \\
\hline 1. & 2. \\
\hline $\begin{array}{l}\text { 1. Knowledge } \\
\text { This category includes the study material from } \\
\text { concrete facts to holistic theories. }\end{array}$ & $\begin{array}{l}\text { The learner } \\
\text { - knows the terms used, knows the } \\
\text { concrete facts; } \\
\text { - knows the method and procedure; } \\
\text { - knows the rules and principles. }\end{array}$ \\
\hline $\begin{array}{l}\text { 2. Understanding } \\
\text { Understand the importance of the material studied. } \\
\text { As an indicator of the ability, as an expression of the } \\
\text { material from one form to another, from one } \\
\text { language to another (e.g., from the form of words } \\
\text { to the form of mathematics). } \\
\text { As an indicator of understanding, the student can } \\
\text { interpret the material or give an approximate }\end{array}$ & $\begin{array}{l}\text { The learner } \\
\text { - understands: interprets, explains } \\
\text { materials, facts, rules and principles } \\
\text { - interprets schemes, graphs, } \\
\text { diagrams; } \\
\text { - converts words into mathematical } \\
\text { expressions; } \\
\text { - approximate the future }\end{array}$ \\
\hline
\end{tabular}




\begin{tabular}{|c|c|}
\hline $\begin{array}{l}\text { description of the consequences of the event. Such } \\
\text { results predominate in a simple understanding of } \\
\text { the material. }\end{array}$ & $\begin{array}{l}\text { consequences based on the available } \\
\text { data }\end{array}$ \\
\hline $\begin{array}{l}\text { 3. Application } \\
\text { This category means the ability to use the material } \\
\text { studied in new situations in specific contexts. This } \\
\text { includes the application of rules, methods, } \\
\text { concepts, laws, principles, theories. Appropriate } \\
\text { learning outcomes require a higher level of mastery } \\
\text { than understanding the materials. }\end{array}$ & $\begin{array}{l}\text { The learner } \\
\text { - Uses concepts and principles in new } \\
\text { situations; } \\
\text { - applies laws, theories in specific } \\
\text { practical situations; } \\
\text { - demonstrates the correct } \\
\text { application of a method or procedure. }\end{array}$ \\
\hline $\begin{array}{l}\text { 4. Analysis } \\
\text { The structure of this type of material can clearly } \\
\text { visible by means to know the distribution of parts. } \\
\text { This includes distinguishing individual parts from a } \\
\text { whole, identifying the interrelationships between } \\
\text { them, understanding the principles that make up a } \\
\text { whole, and learning outcomes are characterized by } \\
\text { a higher intellectual level than comprehension and } \\
\text { application, as it understands both the content of } \\
\text { the learning material and its internal structure. } \\
\text { requires }\end{array}$ & $\begin{array}{l}\text { The learner } \\
\text {-expresses hidden (uncertain) } \\
\text { assumptions } \\
\text {-can see errors and shortcomings in } \\
\text { thinking logic. } \\
\text {-identifies the difference between } \\
\text { evidence and causes. } \\
\text {-evaluates the importance of data. }\end{array}$ \\
\hline
\end{tabular}




\section{Synthesis}

This category means being able to add elements together to form a whole with novelty. Such is the sum of information (speech, report), action plan, or generalized links (schemes for organizing existing data) may be a new product. Appropriate learning outcomes involve creative activity to create new schemes and structures.

\section{The learner}

-writes a short creative essay and suggests a plan for the experiment. -Applies knowledge in various fields is used to create a plan to solve a problem.

\section{Assessment}

This category means the ability to assess the importance of a particular material (confirmation, work of art and research data) for a specific purpose. The student's opinions should be based on clear criteria. The criteria can be internal (structural, logical) and external (according to the intended purpose). This category involves the acquisition of assessment opinions based on the learning outcomes of all previous categories and clearly limited criteria.

\section{The learner}

-evaluates the logic of composing material in the form of written text.

-evaluates the relevance of the findings to the available data.

-evaluates the importance of a particular product of activity based on internal criteria based on external quality criteria.
'According to Blum's theory, the goals of academic science are concretized in two stages. In the first stage the course objectives are divided, in the second the daily, current goals of the educational activity. The activities are formalized in the form of leading types.
To conclude, we can say that new elements of content for students are identified and classified within each section and the appropriate intellectual operations necessary for the required level of mastery are identified. In order for diagnostics to be fully diagnostic and reproducible, it is necessary to adopt criteria for achieving each goal. In other 
words, the learning goal should be described as making the same judgment about achieving it.

\section{REFERENCES}

1. M.F. Atoyeva. Interdisciplinary relations in physics course at specialized secondary education. The Way of Science.-Volgograd, 2016. №9 (31). - P.22-24.

2. M.F. Atoyeva. The significance of periodicity at teaching physics. The Way of Science. - Volgograd, 2016. -№ 10 (32). - P.62-64.

3. M.F. Atoyeva. Use of Periodicity in Teaching Physics. Eastern European Scientific Journal. -DüsseldorfGermany, 2017. № 4. -P. 35-39.

4. M.F. Atoyeva. Didactic foundations of inter-media relations in the training of university students. International Scientific Journal. Theoretical \& Applied Science. p-ISSN: 2308-4944 (print) e-ISSN: 2409-0085 (online). Year: 2020 Issue: 06 Volume: 86, P. 124.

5. M.F. Atoyeva, R. Safarova. Pedagogical integration as a means of forming professionally important qualities among students of a medical university. Academicia. ISSN: 2249-7137 Vol. 10, Issue 8, August 2020. Impact Factor: SJIF $2020=7.13$ ACADEMICIA: An International Multidisciplinary Research Journal https://saarj.comэ.

6. Use of alternative energy sources at the natural sciences lessons. SK Kakhkhorov, HO Juraev, MF Atoeva. The Way of Science. 36, 148

7. Mukhamedjanova Sitorabegim. Use of communicative culture and semantic structures in English lessons for ESP learners. European Journal of Research and Reflection in Educational Sciences // Volume 7 Number 12, 2019. ISSN 2056-5852. Progressive Academic Publishing, UK. P. 98-101.

8. Sitorabegim Mukhamedjanova Dzamolitdinovna. Communicative culture as a condition for improving the training of future specialists . European Journal of Research and Reflection in Educational Sciences // Volume 7 Number 12, 2019. ISSN 20565852. Special Issue on "Education in Uzbekistan", Progressive Academic Publishing, UK. -P. 88-92.

9. Sitorabegim Djamolitdovna Mukhamedjanovna. Pedagogical conditions for the development of communicative culture in higher education specialists. International Scientific Journal. ICJ Theoretical \& Applied Science (Impact factor 8.716) Philadelphia, USA. ISSN: 2409-0085. Volume 80; Issue 12. December 30, 2019. -P. 356-359.

10. Mukhamedjanova Sitorabegim Djamolitdinovna. Improvement of pedagogical conditions for the development of communicative culture in higher education specialists. International Journal of Psychological Rehabilitation (Indexed by Scopus) London, UK. ISSN: 1475-7192. Volume 24; Issue 3. February, 2020. - P. 430436. 